\title{
Numerical analysis of groundwater flow and potential in parts of a crystalline aquifer system in Northern Ghana
}

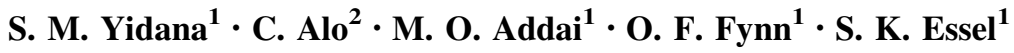

Received: 16 August 2013/Revised: 22 August 2014/Accepted: 16 March 2015/Published online: 9 April 2015

(C) Islamic Azad University (IAU) 2015

\begin{abstract}
The groundwater flow system in a crystalline aquifer system in parts of Northern Ghana was simulated and calibrated under steady-state conditions. The objective was to estimate the regional distribution of a key aquifer hydraulic parameter (the hydraulic conductivity) and recharge and also to predict possible effects of different abstraction and groundwater recharge scenarios on the sustainability of groundwater resources in the area. The study finds that the hydraulic conductivity field is quite homogeneous and has values ranging between 1.70 and $2.24 \mathrm{~m} /$ day. There is an apparent dominance of regional groundwater flow systems compared to local flow systems. This is probably attributed to the homogeneity in the hydraulic conductivity field and the absence of complex local relief. Estimated groundwater recharge ranges between 0.036 and $0.164 \mathrm{~m} / \mathrm{yr}$ representing 3.6 and $16.4 \%$ of the local annual precipitation, respectively. Substantial subsurface inflows and outflows have also been simulated through general head boundaries. The simulation suggests that under the current conditions of groundwater recharge estimated at calibration, the system can sustain increment in groundwater abstraction by up to $50 \%$ without any significant changes in the groundwater flow geometry and drawdowns in the hydraulic heads. However, significant drawdowns will be expected in the wake of $100 \%$ increment in groundwater abstraction and a reduction in recharge by $10 \%$ during the 20 -year period. Under such
\end{abstract}

C. Alo

aloc@mail.montclair.edu

1 Department of Earth Science, University of Ghana, Legon, Accra, Ghana

2 Department of Earth and Environmental Studies, Montclair State University, Montclair, NJ 07043, USA conditions, the flow geometry will significantly be altered and a reversal in groundwater flow will be observed.

Keywords Groundwater flow - Hydraulic conductivity . Lawra district · Recharge

\section{Introduction}

The development and sustainable management of groundwater resources to meet various needs in the society has been understood to represent one of the major buffers against the unremitting effects of climate change/variability in the spatial and temporal distribution in the patterns of rainfall in Northern Ghana (Yidana 2013). Currently, rain-fed agriculture is the mainstay of most of the communities in the area. This practice is very much dependent on the reliability of the rainfall patterns in the area. Recently, the patterns have been observed to be quite erratic apparently due to effects of climate change/variability. Crop losses attending these erratic rainfall patterns in the country have been noted for sometime now. This is a disincentive to agricultural practice and has thus led to a mass exodus of the youth to urban centres in the south of the country, especially during the dry season. Since there is only one rainy season in the year, farming activities are currently limited to that season alone, and the dry season is usually one of no economic activity. This accounts for the high levels of migration of the youth from the northern parts of the country to the south in search of non-existent jobs, especially during the dry season.

The efficient and effective development and exploitation of groundwater resources for various uses holds promise for a vibrant agricultural sector and sustainable livelihoods (Yidana 2011a, b), especially in the northern parts of 
Ghana. It would improve the economic status of communities in the north and enhance national food security. It is in the furtherance of this objective that detailed hydrogeological investigations are required to document the properties of local and regional aquifer systems in the northern parts of the country. Several wells have been drilled to different depths in an attempt to access groundwater for various uses in the terrain. However, since these wells were not drilled deliberately to provide access routes to the aquifers for scientific research purposes, the records of most of them lack sufficient data to thoroughly define and characterize the aquifers in the area. A few of these wells have well-documented well logs which are useful in delineating the spatial pattern of distribution in the thickness and depth of the major hydrostratigraphic units. Static water levels have also been documented in most of the existing wells. It is therefore possible to characterize the general groundwater flow pattern in parts of the area to provide initial basis for detailed regional hydrogeological investigations.

Groundwater flow models have been used all over the world to provide detailed characterization of the general flow pattern and regional variations in key aquifer parameters. They have often been used to evaluate regional aquifer groundwater resources potential for informed management decisions to be made. Details of such studies have been copiously documented in the literature. Numerical groundwater flow models at the regional and local scales have been used extensively to provide detailed analyses of seawater effects on coastal aquifers (e.g. Karahanoglu and Doyuran 2003; Zhang et al. 2004; Barazzuoli et al. 2008; He et al. 2008; Lin et al. 2009). They have also been applied to quantitatively analyse groundwater budget components for informed management decisions to be taken (e.g. Boronina et al. 2003; Ebraheem et al. 2003; Park and Aral 2004; Uddameri and Kuchanur 2007). Where there are concerns over drawdowns due to abstraction from municipal supply wells, groundwater flow models have been used to delineate capture zones for protection and proper management (Barry et al. 2009). Numerical groundwater flow models have also been widely modified to simulate contaminant transport processes at all scales and are therefore useful decision support systems in the management of groundwater contamination (e.g. Neville et al. 2000; McLaren et al. 2000; Spiteri et al. 2007). When carefully calibrated with reliable and representative field data, it is possible to use numerical groundwater flow models to constrain aquifer parameters and their spatial variations. For instance, Ophori (1999) constrained the spatial and vertical variations in the permeability of a regional aquifer system through model calibration. A similar approach was applied by Yidana (2011a, b), Yidana et al. (2012) and Attandoh et al. (2013) in parts of Ghana. Characterization of the spatial pattern of behaviour of key aquifer hydraulic parameters is an important aspect of detailed regional hydrogeological investigations. Since numerical groundwater flow models are based on approximations of the groundwater equation under various assumptions of boundary and initial conditions, their accuracy and reliability depends on the size of the data, the validity of the assumptions made, the accuracy of the data used and the expertise of the modeller. When carefully constructed, calibrated and validated, groundwater flow models are the best tools for predicting several future groundwater development scenarios, natural environmental changes and climate change/variability, amongst others. Where sufficiently detailed monitoring data are available, reasonably accurate predictions of the characteristics of the aquifer system can be made. It is in the light of this that groundwater flow models have been extensively used in decision-making processes, especially where extensive groundwater abstraction is required in the face of various environmental and economic constraints, and have been widely validated as useful management tools. The weakness of numerical models relates to their apparent non-uniqueness, especially when the data are relatively scanty. In addition, where there is insufficient field investigations to properly conceptualize the physical domain, models can produce unreliable results leading to bad decisions. However, where sufficient data are available, numerical models provide more reliable and continuous information on aquifer parameters and groundwater resources potential of an area than the conventional pumping tests which provide point data on aquifer parameters (Yidana and Chegbeleh 2013). One would need to drill so many wells to the same objective of detailed spatial aquifer characterization. The associated costs would be too prohibitive to be feasible. Tracer tests (Leibundgut et al. 2009) have been used in other areas to assist in estimating aquifer parameters and thus achieve similar results of spatial characterization of aquifer properties. The major setback relates to the assumptions, as they may not apply at a relatively large-scale field project. Moreover, the cost of setting up a comprehensive tracer study is currently too prohibitive to be realistically used in large-scale hydrogeological assessment of aquifer parameters. Therefore, numerical groundwater flow models have been consistently used in most regional hydrogeological investigations and groundwater resources management studies.

In Ghana and much of the West African subregion, the utility of groundwater flow models in management decisions regarding commercial groundwater abstraction to support irrigation schemes has not been the practice over the years. The current study is based on steady-state groundwater data from a crystalline aquifer system in the Lawra area in Northern Ghana. It forms one of the initial 
stages of detailed hydrogeological analyses which will ultimately inform the proper management of groundwater resources for commercial ventures. Similar models were constructed and calibrated to describe steady-state groundwater flow conditions in parts of a slightly metamorphosed sedimentary aquifer system in Northern Ghana (Lutz et al. 2007; Attandoh et al. 2013; Yidana and Koffie 2014) and have provided useful information on approximate groundwater recharge rates from precipitation and the spatial variations in key aquifer parameters in the area. Lutz et al. (2007) and Attandoh et al. (2013) applied their calibrated steady-state models on limited scales, to predict some development scenarios. In this study, a calibrated model is being used to characterize the general groundwater flow system in the Lawra part of the crystalline basement aquifer system (Banoeng-Yakubo et al. 2010) and predict the patterns of variability in the hydraulic head in response to abstraction and recharge scenarios.

\section{The study area}

\section{Location and local geography}

The Lawra district (Fig. 1) is one of the nine districts in the Upper West Region. It lies in the north -western corner of the Upper West Region in Ghana between latitudes $2^{\circ} 25^{\prime \prime} \mathrm{W}$ and $2^{\circ} 45^{\prime \prime} \mathrm{W}$ and longitudes $10^{\circ} 20^{\prime \prime} \mathrm{N}$ and $11^{\circ} 00^{\prime \prime} \mathrm{N}$. It is bounded to the east and south by the Jirapa and Lambussie-Karni district and to the north and west by the Republic of Burkina Faso. The total area of the district is about $1051.2 \mathrm{Km}^{2}$, with a total population of 87,525 which is about $15.2 \%$ of the region's total population of 576,583 (Ghana Statistical Service 2000). Majority of the people are subsistence farmers. The district is gently rolling with a few hills ranging between 180 and $300 \mathrm{~m}$ above sea level. It is drained by the main river, the Black Volta, to the west making a boundary between the district and the Republic of Burkina Faso. The Black Volta has several tributaries in the district; notable amongst them are the Kamba/Dangbang, Nawer, Duodaa and Kokoligu-baa. Most of the tributaries of the Black Volta in the area are ephemeral, and their flows do not last the entire year. The high annual temperatures and low relative humidities are responsible for the drying out of some of the tributaries.

The district lies within the Guinea Savannah zone which is characterized by short grasses and few woody plants. Common trees in the district consist of drought- and fireresistant trees such as baobab, dawadawa, shea trees and acacia. The vegetation is very congenial for livestock production, which contributes significantly to household incomes in the district. Transpiration is reduced considerably, and this affects average annual rainfall totals. The climate of the district is tropical continental type with the mean annual temperature ranging between 27 and $36{ }^{\circ} \mathrm{C}$. Precipitation averages just over $1050 \mathrm{~mm}$, while potential evapotranspiration is about $1770 \mathrm{~mm}$ (Pelig-Ba 2000). The period between February and April is the hottest. There are two main seasons: rainy (wet) and dry seasons in the area. Between April and October, the tropical maritime air mass blows over the area which gives the only wet season in the year. In recent times, the rainfall pattern has been observed to be quite erratic, resulting in crop failure. These erratic rainfall patterns have been the cause of the observed migration of the youth in the area to the major cities in the south of Ghana. Between November and January, the district experiences the Harmattan; a cold but dry wind which comes with the north-east trade winds blowing over the Sahara Desert.

\section{Regional and local geology}

The study area is basically underlain by the rocks of the Birimian and its intrusive granitoids. The Birimian is part of the subprovinces that make up of the basement complex that underlies about $54 \%$ of Ghana based on geology and groundwater conditions (Gill 1969). Traditionally, Junner (1935, 1940) subdivided the Birimian Supergroup into two parts: the Lower and Upper Birimian. The Lower Birimian consists of dacitic/rhyodacitic volcaniclastics, greywackes, phyllites, argillites and chemical sediments (Leube and Hirdes 1986). The Upper Birimian is mainly made up of tholeiitic basalts with intercalated volcaniclastics, pyroclastic lava and hypabyssal basic intrusions. Most of the rocks have metamorphosed into calcareous chlorite schists and amphibolites (greenstones). Pillow structures indicating subaqueous eruption of the original basaltic lavas are commonly observed.

The rock types present in the Lower Birimian sedimentary belt are greywackes with turbidite features, phyllites, slates, schists, weakly metamorphosed tuffs and sandstones. Some of the phyllites contain pyrite, and finely divided carbonaceous matter is present in most of them. Silicification is common in the phyllites, particularly towards the boundary with the Upper Birimian. Four main types of granitoids are recognized in the Birimian of Ghana. They include Winneba, Cape Coast, Dixcove and Bongo granitoids (Junner 1940; Kesse 1985).

However, in the study area, only the Cape Coast (basintype) granitoids and Dixcove (belt-type) granitoids can be seen to outcrop in the study area. The Cape Coast granites occur only within the Birimian sedimentary basins.

The study area is dominated by metamorphosed lavas, hypabyssal basic intrusives, pyroclastic rocks, phyllites, Schists, tuff and greywackes of the Lawra belt (Fig. 2). These account for over $95 \%$ of the rocks in the area. There 
Fig. 1 A map of the study area showing some of the communities in the area

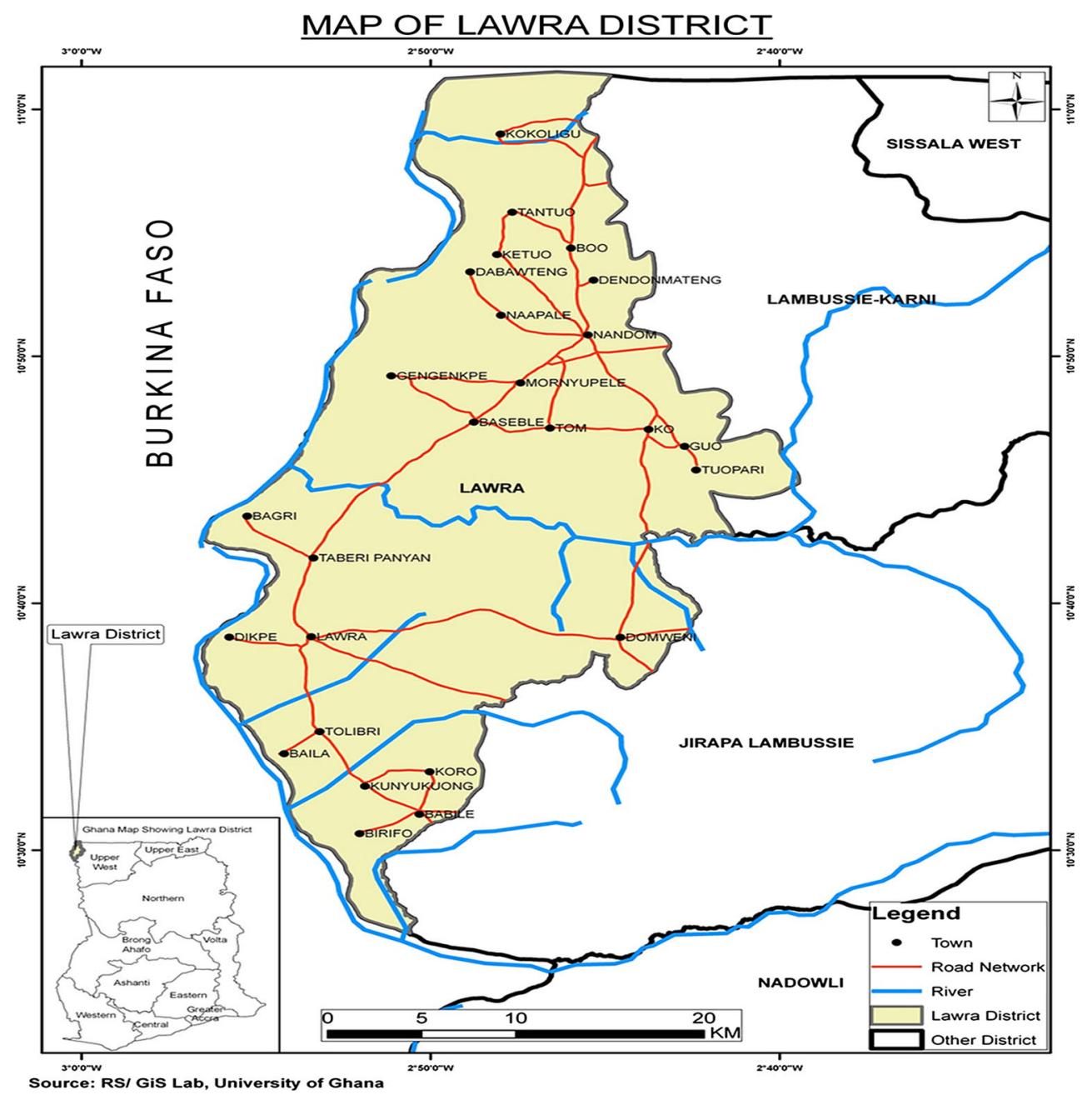

are few outcrops of the belt-type granitoids mainly in the eastern and western parts of the area.

\section{Regional hydrogeology}

There are two hydrogeological provinces defined within the Birimian Supergroup: the Crystalline Basement Province comprising the granitoids and the Birimian Province comprising the metavolcanics and sediments of the Birimian. The occurrence of groundwater in the Birimian rocks depends on secondary structures made up of fractures, veins and faults. The development of secondary permeability is dependent on the nature, aperture, length, density, thickness and the degree of interconnection of the fractures (Atobrah 1980) and in-filling from mineral precipitation. The development of fractures and faults is a direct consequence of the cooling processes and the pressure release due to erosion, compressional and tensional activities during regional tectonic processes. In these rocks, the mode of occurrence of groundwater is basically linked with the nature and thickness of the decomposed zone, rock fractures, joints, quartz veins and pegmatites. Most of the quartz veins and pegmatites are fractured and to some extent brecciated as a result of brittle deformation attending the Proterozoic Eburnean orogenic activities which affected them. The water-bearing and yielding capacities of these rocks depend on the extent of these secondary permeabilities (Banoeng-Yakubo 2000).

The most productive zones in terms of groundwater in the Birimian Province comprise the lower part of the saprolite and the upper part of the saprock which usually complement each other in terms of permeability and storage (Carrier et al. 2008). The upper, less permeable part of the saprolite can act as a semi-confining layer for this productive zone, while the lower, usually saturated part of the saprolite is characterized by lower secondary clay content, thus creating a zone of enhanced hydraulic conductivity. Generally, areas underlain by the Birimian rocks display deeper seated weathering than areas underlain by the granitoids. Banoeng-Yakubo (1989) and Banoeng-Yakubo and Norgbe (1998) identified three types of aquifers in the basement aquifers. These are the 
Fig. 2 A geological map of the study area showing the main rock types

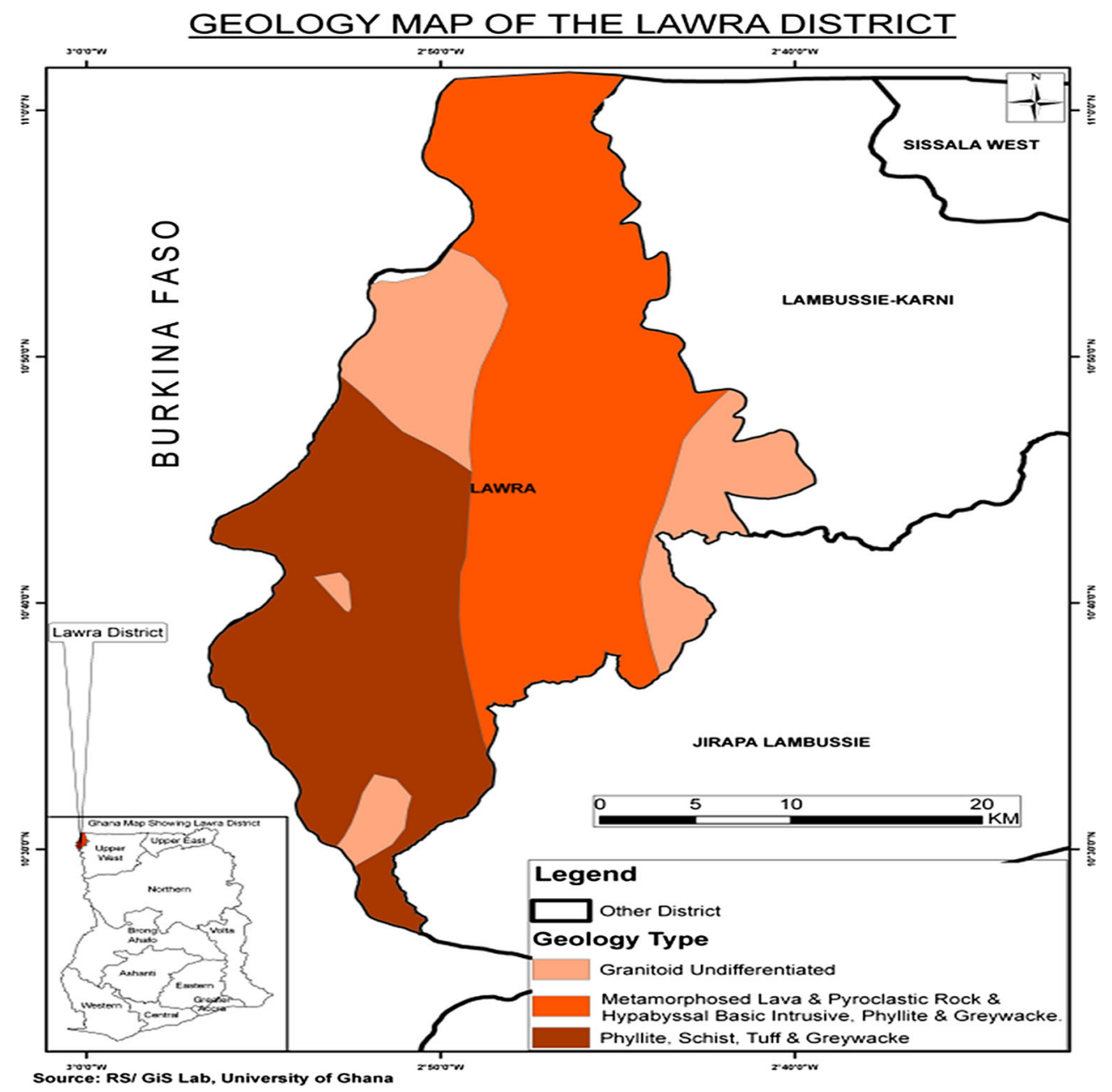

weathered rock aquifers, which are fracture related, the fractured quartz vein aquifers and the fractured unweathered aquifers. In the crystalline basement aquifers, the saprolitic zone is a combination of the top soil, the underlying lateritic soil, the highly weathered zone and the moderately weathered zone. The saprock is the poorly weathered zone. Together, the saprolite and the saprock are the regolith. Borehole depths are varied in the Crystalline Basement Province aquifers. This province is characterized by highly fractured sandstones, phyllites, greywackes, greenstones and schists. Many of them are criss-crossed by fractured quartz veins, and prolific aquifers have been encountered at an average depth of $25 \mathrm{~m}$. The productive wells are completed in the moderately to poorly decomposed zones. The depth of weathering is dependent on the nature of the granitoids and the fissility of the rock. For instance, very productive and high-yielding aquifers are encountered in coarse-grained granites, especially those traversed by fractured quartz veins, and depths of up to $60 \mathrm{~m}$ are not uncommon. Depths of boreholes drilled through rocks of the Birimian and Tarkwaian systems range between 35 and $62 \mathrm{~m}$ with an average of $42 \mathrm{~m}$ (Agyekum 2004). Borehole depths in areas underlain by the granitoids are similar and range between 35 and $55 \mathrm{~m}$, with an average of $50 \mathrm{~m}$ (Carrier et al. 2008). In some areas, the regolith is tapped at relatively shallow depths with relatively shallow hand-dug wells.

Aquifer transmissivity of the productive zones of the Birimian systems ranges between 0.2 and $119 \mathrm{~m}^{2} /$ day, with an average of $7.4 \mathrm{~m}^{2} /$ day. In these aquifers, storativity ranges between 0.003 and 0.008 . Transmissivity within the regolith is slightly higher than that observed in the integrated aquifer system and ranges between 4 and $40 \mathrm{~m}^{2} /$ day with an average of about $10 \mathrm{~m}^{2} /$ day. For the integrated aquifer systems in the Birimian and Tarkwaian systems, borehole yields are generally low and range from 0.48 to $36.4 \mathrm{~m}^{3} / \mathrm{h}$ with a mean yield of $7.6 \mathrm{~m}^{3} / \mathrm{h}$ (Banoeng-Yakubo et al. 2010). Differences in the degree of weathering within the granitoids probably account for the lower yields observed in these rocks. In and around the Lawra district, the zone of weathering is about $137 \mathrm{~m}$ thick (Kesse 1985). 


\section{Materials and methods}

Borehole static water levels and other relevant data on the hydrogeology of the study area were obtained from the office of SAL Consult Limited, a hydrogeological consultancy firm based in Accra. Historical data and information on geology and hydrogeology of the study area were obtained from the Earth Science and the Community Water and Sanitation Agency, CWSA. Relevant maps and geographical information on the study area were obtained from the Department of Geography and Resource Development of the University of Ghana. These pieces of information were used with the lithological logs from the drilling projects to develop a conceptual framework which was then converted into a numerical model. The Groundwater Modelling System, GMS 7.1, was chosen for the conceptualization and numerical modelling. This software package incorporates the United States Geological Survey's Modular three-dimensional Finite Differences groundwater flow modelling code, MODFLOW-2000 (Harbaugh et al. 2000), the Finite Element code, FEMWATER and several solute transport codes. There is therefore an opportunity to choose from a variety of codes, depending on the data available and the objectives to be achieved. Both numerical groundwater flow modelling codes (MODFLOW and FEMWATER) are flexible to use in the GMS system. In this study, MODFLOW was chosen for the numerical simulation since it has been universally very well tested to simulate similar conditions in other places around the world (e.g. Lutz et al. 2007; Barry et al. 2009; Attandoh et al. 2013).

\section{Conceptualization of the domain}

The domain was conceptualized as a single layer since the hydrostratigraphy revealed by the well logs did not suggest significant differences amongst the groundwater-bearing units penetrated by the wells. The thickness of the modelled unit varied from one place to the other based on the thicknesses of the unit penetrated by wells. This variability in the thickness of the aquifer was conceptualized by importing the top and bottom elevations of the aquifer as obtained from well logs, during the conceptualization process. The conceptual model was constructed within the Groundwater Modelling System (GMS 7.1). The entire unit was conceptualized as a confined aquifer since the depth to aquifer $(10-41 \mathrm{~m})$ is considerably high and has the tendency to induce confining to semi-confining conditions. Using the GIS map tools, the geological map of the area was imported and registered to serve as the base map for the construction of the conceptual model. Coverages were created for the hydraulic conductivity field, recharge, observation, general head boundary and abstraction. In the coverage for hydraulic conductivity field, polygons were created to simulate spatial variations in hydraulic conductivity in the area. Initial values were assigned based on knowledge of the characteristics of similar rock types in other parts of the country and the limited pump test data available from the study area. Similarly, the recharge coverage was designed to simulate variabilities in groundwater recharge at different locations in the area. All the wells used in this study are abstraction wells. The current abstraction rates were imported into the abstractions coverage. Table 1 contains details of the abstraction rates associated with the various wells. The top and bottom elevations of the aquifer being modelled were imported using the $2 \mathrm{D}$ scatter point sets. All the vertical boundaries

Table 1 Initial abstraction rates from boreholes used in this study

\begin{tabular}{|c|c|c|}
\hline Northing & Easting & Discharge $\left(\mathrm{m}^{3}\right)$ \\
\hline 10.702 & -2.891 & -103.68 \\
\hline 10.792 & -2.810 & -8.64 \\
\hline 10.879 & -2.795 & -38.88 \\
\hline 10.659 & -2.714 & -43.2 \\
\hline 10.834 & -2.742 & -34.56 \\
\hline 10.826 & -2.748 & -64.8 \\
\hline 10.885 & -2.750 & -23.04 \\
\hline 10.822 & -2.834 & -77.76 \\
\hline 10.866 & -2.781 & -23.04 \\
\hline 10.850 & -2.790 & -23.904 \\
\hline 10.780 & -2.719 & -20.16 \\
\hline 10.657 & -2.718 & -43.2 \\
\hline 10.790 & -2.731 & -115.2 \\
\hline 10.805 & -2.730 & -64.8 \\
\hline 10.852 & -2.796 & -48.96 \\
\hline 10.852 & -2.790 & -21.6 \\
\hline 10.846 & -2.802 & -27.36 \\
\hline 10.988 & -2.795 & -103.68 \\
\hline 10.788 & -2.833 & -103.68 \\
\hline 10.835 & -2.762 & -115.2 \\
\hline 10.832 & -2.770 & -86.4 \\
\hline 10.889 & -2.803 & -115.2 \\
\hline 10.848 & -2.810 & -43.2 \\
\hline 10.679 & -2.896 & -61.92 \\
\hline 10.893 & -2.763 & -25.92 \\
\hline 10.850 & -2.819 & -30.24 \\
\hline 10.667 & -2.721 & -43.2 \\
\hline 10.773 & -2.768 & -27.36 \\
\hline 10.884 & -2.755 & -34.56 \\
\hline 10.806 & -2.717 & -115.2 \\
\hline 10.794 & -2.726 & -77.76 \\
\hline
\end{tabular}


were conceptualized as general head boundaries so that groundwater flow across boundaries could be sufficiently represented. Confining conditions were conceptualized for the bottom of the aquifer as the material below the aquifer zone is obviously confining.

\section{Development of the numerical model}

MODFLOW-2000 was initialized, and a grid system was developed using a pre-defined grid dimension in the conceptualization process. The conceptual model was then mapped to MODFLOW and converted to a numerical model to simulate flow under steady-state conditions. The top and bottom elevation data that were imported during the conceptualization process were then mapped to MODFLOW top and bottom elevations, respectively, and then interpolated to cover the entire domain using ordinary kriging. It was then possible to obtain spatial variations in the thickness of the aquifer using the top and bottom elevations. The starting heads were automatically generated from the data imported during the conceptualization. MODFLOW was then simulated for steady-state conditions. It was not possible to develop a transient model due to the lack of historical water level data from the study area.

\section{Model calibration}

Model calibration is the process of tuning the model to reflect field conditions. It is only the calibrated model that can be used to simulate scenarios and characterize the hydraulics of the terrain being modelled. The model was manually calibrated initially by varying the hydraulic conductivities and recharge. The process was later switched to the automatic approach through the parameter estimation (PEST), and the pilot point method was used to simulate the hydraulic conductivity. The pilot point approach makes it possible simulating a continuous hydraulic conductivity field for proper characterization of the aquifer. A calibration target of $\pm 1.5 \mathrm{~m}$ was set to aid in the calibration process. This means that the model-computed and observed data hydraulic heads should not be different by more than $1.5 \mathrm{~m}$ at the end of the calibration.

\section{Sensitivity analysis}

The purpose of sensitivity analysis is to measure the stability of the model in the face of subtle changes in some of the model parameters. It is performed by making slight variations in the key parameters and noting the effects on the calibrated model. When a calibrated model shows significant departures from calibration after slight variations in the key parameters, it is said to be unstable and can therefore not be relied upon to predict scenarios. Under such circumstances, the model will have to be recalibrated. In this study, sensitivity analysis was automatically carried out in the process of the PEST and generated histograms which can be used to assess the stability of the model with respect to each of the input parameters.

\section{Analysis of scenarios}

A transient model is the best suited to simulate various scenarios of stresses on aquifers. This is because it is the transient model that simulates changes in aquifer storage with time. In this study, however, due to the absence of transient data to calibrate a transient model, the calibrated steady-state model was used to simulate the effects of increased groundwater abstraction by $20,30,50$ and $100 \%$ under the same conditions of recharge. Scenarios of increasing abstraction by $20,30,50$ and $100 \%$ were then simulated with scenarios of decreasing groundwater recharge by $10,20,30$ and $50 \%$. These scenarios were determined somewhat arbitrarily to provide a preliminary test of the capacity of the system to contain probable stresses. Although not a transient model, the simulation of these scenarios will provide the same information regarding the tolerable groundwater abstraction rates in the area. Simulation of such scenarios would not be significantly different if a transient model was used.

\section{Results and discussion}

\section{General groundwater flow}

The calibrated model suggests a general NW groundwater flow pattern in the area (Fig. 3). This is in tune with the local structural grain of the Lawra belt. Groundwater flow in the area is therefore an apparent delineation of the local structural geology. It is apparent that the local structural entities that control groundwater flow may have been influenced by the events which led to the observed orientation of the belt. In most parts of the country, a general NNE-SSW structural orientation is observed (Kesse 1985). This has been supported by numerical groundwater flow models (e.g. Yidana 2011a, b; Yidana et al. 2011; 2012; Attandoh et al. 2013). The Lawra belt is about the only one oriented NNW-SSE. It is therefore possible to predict the local structural trend using a calibrated groundwater flow model as demonstrated in this study. The finding also suggests that the structural entities may indeed be largely interconnected to result in the observed flow pattern. Local flow systems are less obvious and the regional systems appear to dominate the general groundwater flow in the area. This usually occurs when the local relief is less 
Fig. 3 Potential field resulting from the calibration of the model under steady-state conditions

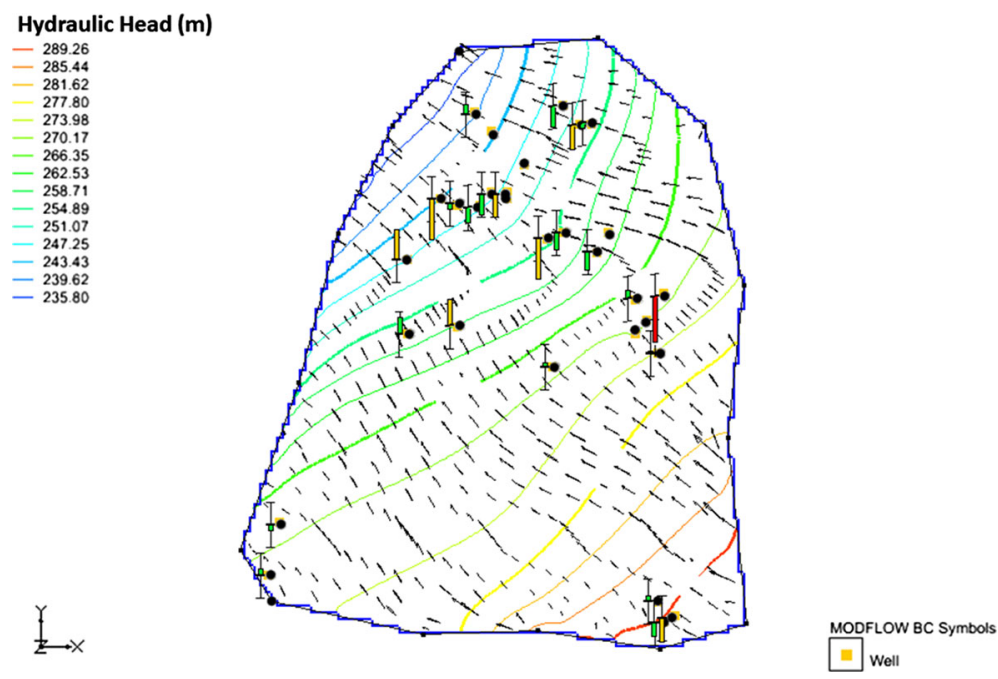

complex and where local aquifer heterogeneities are less pronounced. Where the terrain is hummocky with complicated relief, local flow systems are much more pronounced as the flow pattern takes the shape of the local topography (Freeze and Cherry 1979; Fetter 2001). Similar scenarios are observed where aquifer heterogeneities are very much pronounced and where the local relief is less complex. In such cases, restricted flow and refraction of flowlines across boundaries of contrasting hydraulic properties result in complex local flow systems. The outcome of the current study confirms the general relief in the area and suggests a general regional discharge in the north-western parts of the terrain where the observed hydraulic heads are the lowest. The flow system appears to be controlled by subsurface flow across boundaries and not necessarily local direct recharge from precipitation as the data suggest higher direct recharge in the north which happens to have the lowest hydraulic heads.

Figure 4 shows the relationship between the observed and model-computed hydraulic heads and suggests a reasonably good calibration of the model under the presumed steady-state conditions. The Pearson correlation coefficient, $r$, for the relationship between the observed and model-computed hydraulic head data is 0.98 , and the coefficient of regression, $R$-square, is 0.975 . The uniqueness of models calibrated in this fashion has been challenged in the analyses of previous researchers (e.g. Konikow and Bredehoeft 1992; Jackson 1992). They contend that the non-uniqueness of such models lies in the fact that several different sets of data of aquifer parameters are capable of yielding the same level of calibration in models. However, it has been proven over time that when the data are sufficiently large and representative of the domain as is the case with the current study and the model is carefully calibrated (Ophori 1999), a reasonably accurate representation of the

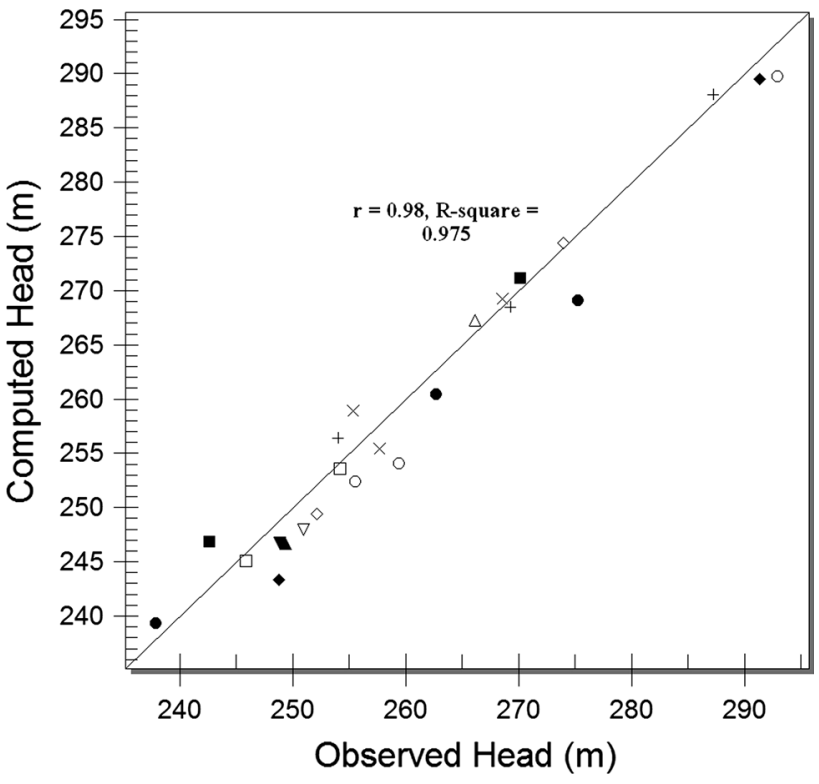

Fig. 4 Relationship between the model-computed and observed hydraulic heads at calibration of the model

flow geometry and groundwater conditions can be achieved. Furthermore, the problem of apparent non-uniqueness is not the exclusive preserve of numerical groundwater flow models, as every system which is based on calibrated models is subject to the same limitation.

\section{Groundwater recharge}

Assessment of groundwater recharge is an important aspect of the overall management strategy for the resource to ensure sustainability. It is the amount and spatial and temporal variations in groundwater recharge that will determine optimal groundwater abstraction rates in an area. 
In this study, the groundwater recharge determined at calibrated was adjudged representative of the annual input from direct precipitation and can therefore form the basis of assessing the viability of the resource. Estimated depth of groundwater recharge in the area ranges between 0.036 and $0.164 \mathrm{~m} /$ day, respectively, representing 3.6 and $16.4 \%$ of the average annual precipitation in the area. This is compatible with groundwater recharge estimated for other parts of the terrain and is consistent with the range of groundwater recharge expected for such a terrain. This much direct recharge from precipitation can sustain current abstraction rates if properly maintained. An attempt was made to simulate inputs through subsurface flows during the model calibration. However, it was observed that although subsurface inflows are substantial, they are exactly balanced by outflows largely through the northern extremities of the terrain. If groundwater abstraction rates increase much more substantially within the study area, the flow geometry is likely to be significantly altered to ensure that such subsurface inflows are retained within the terrain for optimal development and utilization. This can potentially affect ecosystems and regionally recharged aquifers in extreme north of the country, which depend on such subsurface flows for sustenance. The observed groundwater recharge appears to be significant compared to the observed groundwater abstraction rates in the area. However, climate change/variability may affect the spatial and regional distribution of groundwater recharge in the terrain. Analyses of such trends may be performed through a transient groundwater flow simulation. This will require time-variable hydraulic head and flow data for effective calibration. Such transient data are currently unavailable, and the findings of this research will form the appropriate basis for developing current management plans for groundwater resources in the area. In addition, the findings from the current study will form initial conditions upon which a transient flow simulation can be performed for the area. Transient groundwater flow simulations would also assist in constraining regional and local groundwater recharge areas for delineation and protection. This is critically important in the study area in particular and the entire Voltaian Basin in general. It is the proper characterization of the groundwater recharge regime that will provide the appropriate platform for the development of insightful and nationally useful decision support base for the effective management of groundwater resources for commercial ventures.

\section{Hydraulic conductivity field}

Aquifer hydraulic conductivity is an important parameter which provides insight into the character and quality of the aquifer and assists in understanding observed flow patterns.
Good estimates of aquifer hydraulic parameters can be obtained from properly calibrated models (Fitts 2002). The hydraulic parameters estimated in such a fashion are usually large-scale average values, whose level of uncertainty may be attributed to uncertainties in some of the known data, and the incomplete knowledge of the nature of the aquifer material. The conceptual model upon which the current study was conducted was developed from a fairly representative set of lithological well logs from the area. In addition, the nature of the aquifer is fairly known from the literature. The degree of uncertainty is therefore reduced. Estimated hydraulic conductivity at calibration of the model is as illustrated in Fig. 5 and suggests that the hydraulic conductivity field for much of the area is largely homogeneous as it ranges between 1.70 and $2.24 \mathrm{~m} /$ day. The apparent homogeneity in the hydraulic conductivity field is probably responsible for the flow system observed in Fig. 3. Yidana et al. (2011) estimated the hydraulic conductivity of aquifers in similar rocks in the south of the country. A hydraulic conductivity field containing values in the range of 0.99 and $19.4 \mathrm{~m} /$ day was obtained, and the heterogeneity in the hydraulic conductivity field was amply suggested in the detail of the flow system. A similar approach in the Densu Basin in Southern Ghana resulted in a range of 2-40 m/day (Yidana et al. 2012), suggesting a significantly heterogeneous aquifer system. The observed aquifer transmissivity data from limited pump tests carried out in sections of the crystalline basement aquifer system (Dapaah-Siakwan and Gyau-Boakye 2000; BanoengYakubo et al. 2010) appear to be consistent with the range of hydraulic conductivities obtained from the current and previous studies. For a crystalline aquifer system where the hydrogeological properties are based on the presence and degree of fracturing and/or weathering, there are clear differences at different locations of the crystalline basement aquifer province (Banoeng-Yakubo et al. 2010). The observed narrow range of values computed in the current study area may be attributed to relatively lower scale of the study.

Groundwater flow in fractured aquifer systems can be described in three ways: the continuum approach, the discrete approach and the dual-porosity approach (Fetter 2001; Anderson and Woessner 2002; Fitts 2002; Hiscock 2005). The discrete fracture approach is used where the scale of the problem is small and involves a laborious examination of each fracture system in the network. In the continuum approach, the location and orientation of each fracture are immaterial, and the entire system is considered as a representative porous material. Estimates of groundwater hydraulic parameters in fracture- and/or weatheringcontrolled aquifers take the pattern of the continuum approach, which results in regionally averaged values of the hydraulic parameters. Although this practice simplifies the 
Fig. 5 Hydraulic conductivity field at the end of calibration of the model

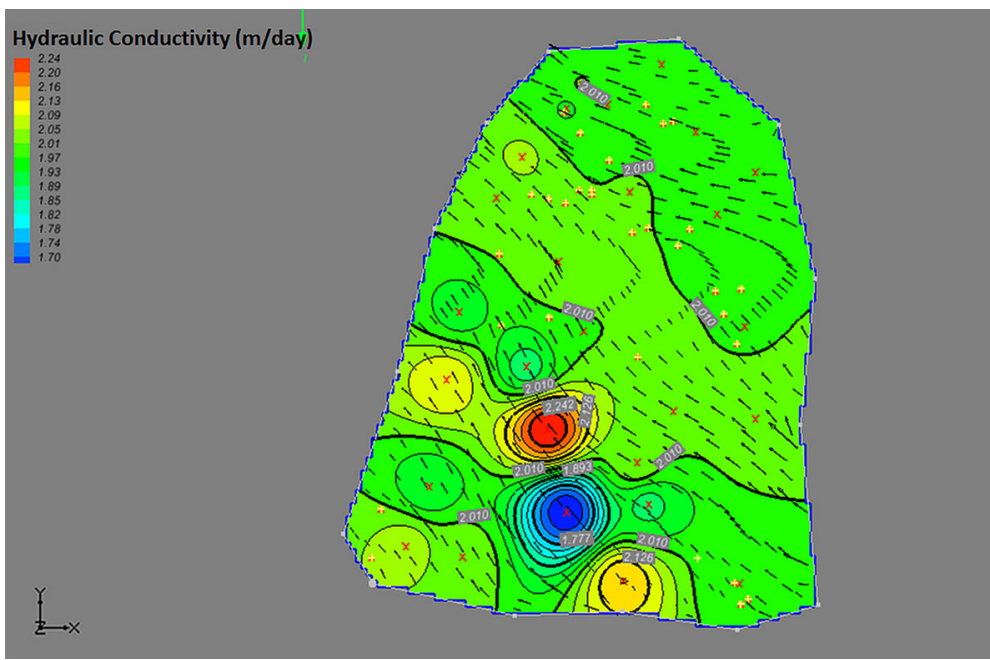

system, it provides sufficient basis for the regional assessment of an aquifer for management purposes. Most numerical groundwater models in fractured systems use this approach as a simplification of the otherwise complex system. The dual porosity considers the issues of primary and secondary permeabilities together, and the flow system is adjudged to have resulted from the combination of the two. This applies when the rock also has primary permeability. It is a very laborious exercise which is practically difficult to undertake.

The model developed in the current study is a hybrid of the continuum and dual-porosity approaches and clearly highlights areas of significant hydraulic conductivity imposed by high levels of fracturing and/or weathering of the rock to enhance its hydrogeological properties. The framework of the discretization process during model conceptualization makes it possible assigning probable ranges of hydraulic conductivity values to different locations. This was abundantly utilized in distinguishing different areas based on the hydraulic conductivity values. In addition, due to the limited scale of the study and the relatively high density of wells, the structural entities are most likely to be largely interconnected to ensure continuity in the flow. The south-central parts of the study area (Fig. 5) indicate areas of the highest hydraulic conductivity, resulting possibly from enhanced permeabilities attending the combination of fracturing and weathering of the rocks.

\section{Scenario analysis}

The calibrated model has been observed to be quite stable to subtle changes in the aquifer parameters and can therefore be used to simulate scenarios within the limits of the calibration error. There is no obvious shift in the nature of the potential field when the current abstraction rates from the existing pumping wells are increased by up to $50 \%$ (Fig. 6). This suggests that the system under the current conditions of groundwater recharge can sustain an increment in the groundwater abstraction by up to half of the current abstraction rates with negligible effects on the system. This scenario may arise when all domestic water needs are served by groundwater from abstraction wells in the area. With the current national average population increase of $2.5 \%$, if groundwater is being abstracted solely to serve the population domestic water needs, the results suggest that the system can sustain annual incremental population demands for 20 years at the current calibrated groundwater recharge rates. The conditions will be completely different if climate change/variability results in concomitant reduction in groundwater recharge and the corresponding reduction in the groundwater available for abstraction. There has been no documented study on the pattern of groundwater recharge variations over the past years. However, in the event of an average reduction in groundwater recharge by $10 \%$ over the 20 -year period, there will be significantly noticeable effects on the flow field if groundwater abstraction increases by up to $50 \%$ as suggested in this study.

On the other hand, if the current abstraction rates increase by up to $100 \%$ under the current groundwater recharge scenarios, the system will record obvious changes in the potential field, but the general groundwater flow pattern will be the same as observed at calibration. Scenarios of $100 \%$ increase in groundwater abstraction can occur if the current water needs double over the next 
Fig. 6 Nature of the hydraulic head pattern in the study area after $50 \%$ increase in the abstraction rates

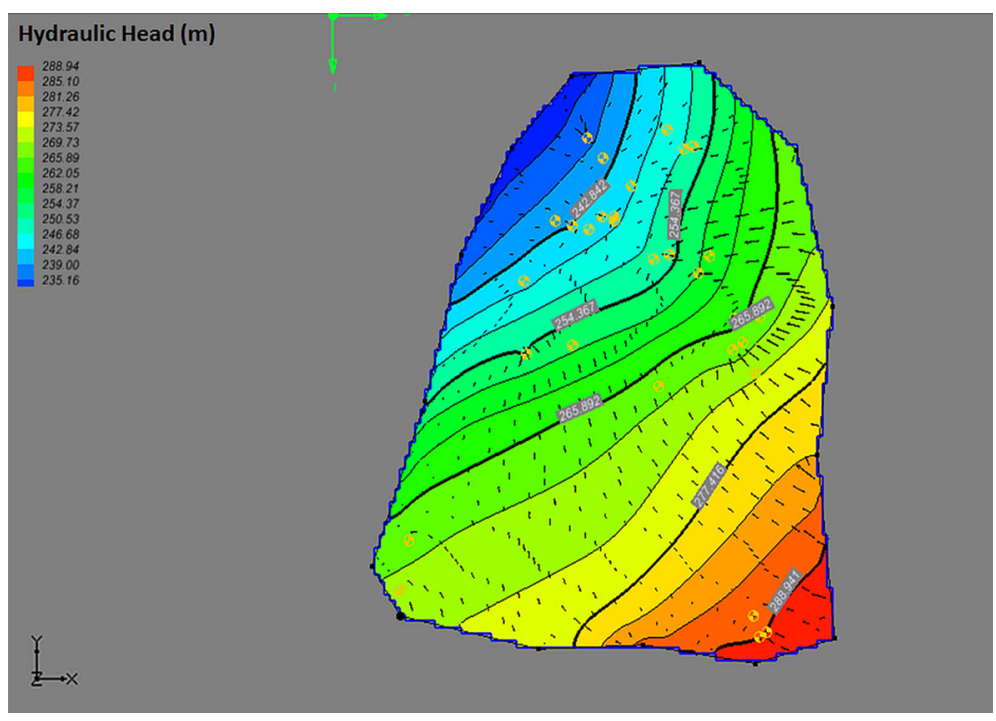

Fig. 7 A suggested reversal of flow in the study area resulting from a $100 \%$ increase in abstraction and a reduction in recharge by $10 \%$

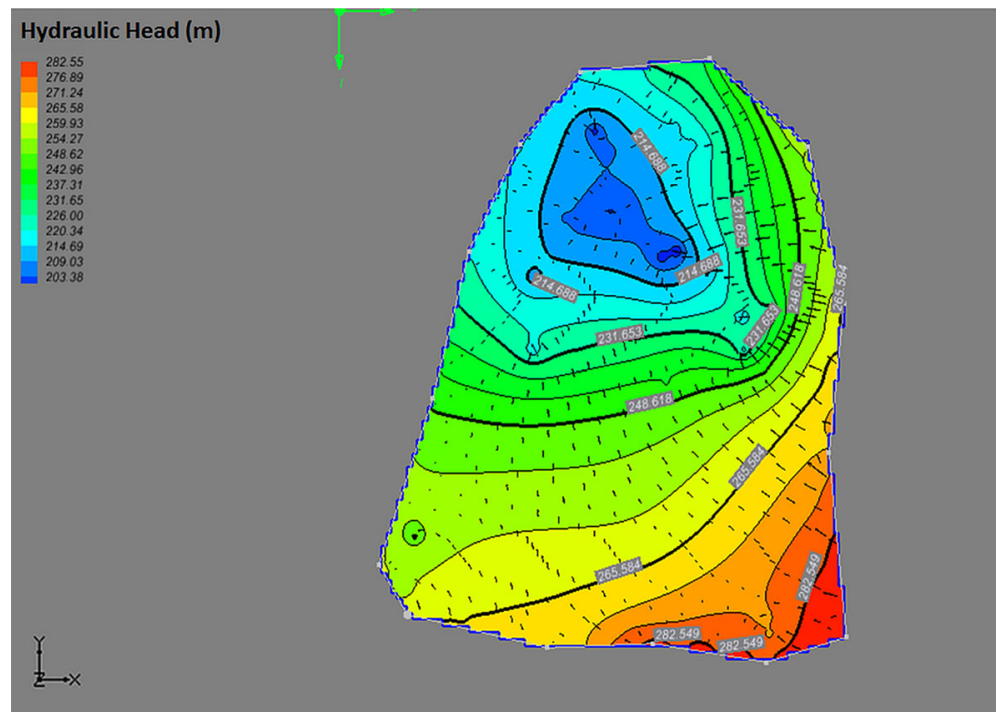

20 years. Significant drawdown in the average hydraulic head will affect the functioning of ecosystems which depend on higher groundwater levels for sustenance. There has been no documented evidence of hydraulic connection between surface flows and the aquifers in the area. However, some of the perennial streams will have their source of sustenance from the subsurface flows. Reductions in groundwater recharge resulting from climate change/variability effects could further lead to drastic drawdowns in the hydraulic head as groundwater abstraction rates increase by $100 \%$. Such a condition will lead to the scenario observed in Fig. 7, where the flow pattern has obviously been changed in some parts of the study area. A reversal of groundwater flow is obvious in Fig. 7, attending the cumulative effects of increased groundwater abstraction rates and reduced groundwater recharge. Under such conditions, subsurface flows will drastically reduce and the observed reversal in the flow geometry could suggest mixed fortunes in terms of groundwater resources development for commercial ventures.

The foregoing scenarios suggest that groundwater abstraction in the study area is significantly limited by the extent of groundwater recharge. Commercial groundwater abstraction for irrigation purposes in addition to the regular domestic water needs will therefore be limited by the amount of water that is received as recharge from 
precipitation on an annual basis. It is therefore suggested that in order to sustain commercial groundwater abstraction for irrigation activities, there is the need to encourage artificial groundwater recharge through the deliberate development of dugouts suited for such purposes in the area. This will significantly increase the annual groundwater recharge in the area and therefore enhance the sustainability of any commercial abstraction of groundwater in the area. There is also the need to carry out extensive investigations to identify prominent local and regional groundwater recharge locations in the terrain for protection so that the current observed recharge does not reduce on account of inundation resulting from development activities.

These analyses are based on the assumption of steadystate conditions which may not necessarily reflect the conditions which may prevail in the event of increasing groundwater abstraction rates and decreasing recharge. It is therefore prudent that a transient model, which takes into account the time-variable nature of groundwater storage in the area, be developed for the area to simulate these timevarying patterns in the groundwater storage.

\section{Conclusion}

This study suggests that groundwater in the crystalline aquifer system in the Lawra area will not be able to sustain any large-scale groundwater abstraction for commercial irrigation. Estimated aquifer hydraulic conductivities range between 1.70 and $2.24 \mathrm{~m} /$ day, suggesting homogeneity in the hydraulic conductivity field in the area, compared to aquifers of similar rocks in the southern part of Ghana. The general groundwater flow pattern is towards the NNW direction, which appears to be consistent with the local structural pattern in the area. Estimated groundwater recharge in the area and constrained through the process of model calibration suggests that about 3.6-16.4\% of annual rainfall reaches the saturated zone. High annual temperatures and low relative humidities have led to significant levels of evaporation of rainwater into the atmosphere leading to reduced surface runoff and groundwater recharge. Significant subsurface flows across the boundaries of the terrain have been suggested through the simulation of the flow. Unfortunately, such inflows are balanced by outflows through the north-western boundaries of the domain. The processes of groundwater recharge and the regional distribution of the hydraulic properties of the unit modelled have led to the apparent dominance of regional groundwater flow systems in the terrain. The findings from this study suggest that at the current recharge rates, the system can sustain groundwater abstraction increases by up to $50 \%$ of the current abstraction rates with minimal net drawdowns in the hydraulic head. This means that the system can sustain annual population increase at the national rate and the concomitant increase in demands from groundwater abstraction in the terrain for the next 20 years at the current groundwater recharge rates. A reduction in groundwater recharge by up to $10 \%$ through the same period will result in drastic drawdowns in the hydraulic head throughout the terrain. An increase in groundwater abstraction by $100 \%$ of the current abstraction rates under the current recharge conditions will result in drastic drawdowns in the hydraulic head, but the general groundwater flow geometry will remain the same as achieved during model calibration. However, an increase in groundwater abstraction by $100 \%$ with a reduction in recharge by $10 \%$ through the same 20 -year period will result in changes in the general flow geometry, especially in the northern parts of the terrain. Significant reversals in the flow in the north-western parts of the terrain will result in net inward subsurface flow.

Acknowledgments The authors are grateful to SAL consult for the well data used in the simulation. We equally appreciate Mr. Gerald Yiran of the Department of Geography and Resource Development, University of Ghana, for assistance in developing the maps of the study area.

\section{References}

Agyekum WA (2004) Groundwater resources of Ghana with the focus on international shared aquifer boundaries. UNESCO-ISARM International Workshop-Managing Shared Aquifer Resources in Africa. B. Appelgreen. Tripoli, Libya, June 2002. UNESCO-IHP VI Series on Groundwater, No. 8, pp. 600

Anderson MP, Woessner WW (2002) Applied groundwater modeling: simulation of flow and advective transport. Academic Press, Elsevier, New York

Atobrah K (1980) Groundwater flow in the crystalline rocks of the Accra Plains, Ghana. Unpublished Ph.D Thesis. Princeton University, Department of Geological and Geophysical Sciences

Attandoh N, Yidana SM, Abdul-Samed A, Sakyi PA, BanoengYakubo B, Nude P (2013) Conceptualization of the hydrogeological system of some sedimentary aquifers in SaveluguNanton and surrounding areas, Northern Ghana. Hydrol Process 27:1664-1676. doi:10.1002/hyp.9308

Banoeng-Yakubo B (1989) Occurrence of groundwater in the basement complex rocks of the Upper Regions of Ghana, M.Sc. dissertation. Obefemi-Awolowo University, Geology Department, Nigeria 
Banoeng-Yakubo B (2000) The application of remote sensing and GIS to hydrogeological studies in the Upper West region, Ghana, Un-published $\mathrm{PhD}$ Thesis, University of Ghana, Legon

Banoeng-Yakubo B, Norgbe B (1998) The hydrogeological representativeness of monitoring boreholes in the upper west region of Ghana. In: Banoeng-Yakubo B, Asiedu DK (eds) Advances in groundwater exploration and development in Ghana. GEODAT Resources, Accra

Banoeng-Yakubo B, Yidana SM, Ajayi JO, Loh YA, Asiedu DA (2010) Hydrogeology and groundwater resources of Ghana: a review of the hydrogeological zonation in Ghana. In: McMann JM (Ed.), Potable water and sanitation. Nova Science Publishers, Inc., ISBN: 978-1-61122-319-4

Barazzuoli P, Nocchi M, Rigati R, Salleolini M (2008) A conceptual and numerical model for groundwater management: a case study on a coastal aquifer in southern Tuscany, Italy. Hydrogeol J $16: 1557-1576$

Barry F, Ophori D, Hoffman J, Canace R (2009) Groundwater flow and capture zone analysis of the Central Passaic River Basin, New Jersey. Environ Geol 56:1593-1603

Boronina A, Renard P, Balderer W, Christodoulides A (2003) Groundwater resources in the Kouris catchment (Cyprus): data analysis and numerical modelling. J Hydrol 271:130-149

Carrier MA, Lefebvre R, Racicot J, Asare EB (2008) Northern Ghana hydrogeological assessment project. 33rd WEDC International Conference, Accra, Ghana

Dapaah-Siakwan S, Gyau-Boakye P (2000) Hydrogeologic framework and borehole yields in Ghana. Hydrogeol J 8:405-416

Ebraheem AM, Garamoon HK, Riad S, Wycisk P, Seif El Nasr AM (2003) Numerical modeling of groundwater resource management options in the East Oweinat area, SW Egypt. Environ Geol 44:433-447

Fetter CW (2001) Applied hydrogeology. Prentice-Hall International Limited, London

Fitts CR (2002) Groundwater science. Academic Press, New York

Freeze RA, Cherry JA (1979) Groundwater. Prentice Hall, Englewood Cliffs, NJ

Gill HE (1969) A ground-water reconnaissance of the Republic of Ghana, with a description of geohydrologic provinces. US Geological Survey Water-Supply paper 1757-K

Harbaugh AW, Banta ER, Hill MC, McDonald MG (2000) MODFLOW-2000, the U.S. Geological Survey modular ground-water model-user guide to modularization concepts and the ground-water Flow Processes. U.S. Geological Survey Open-File 00-92

He B, Takase K, Wang Y (2008) Numerical simulation of groundwater flow for a coastal plain in Japan: data collection and model calibration. Environ Geol 55:1745-1753

Hiscock KM (2005) Hydrogeology. Blackwell Publishing, Principles and Practice

Jackson CR (1992) Hillslope infiltration and lateral downslope unsaturated flow. Water Resour Res 28(9):2533-2539

Junner NR (1935) Gold in the gold coast. Gold Coast Geol Surv Mem 4:67

Junner HR (1940) Geology of the gold coast and western Togoland (with revised geological map). Gold Coast Geol Surv Bull I 1:40

Karahanoglu N, Doyuran V (2003) Finite element simulation of seawater intrusion into a quarry-site coastal aquifer, KocaeliDarıca, Turkey. Environ Geol 44:456-466
Kesse GO (1985) The rock and mineral resources of Ghana. A. A, Balkema/Rotterdam/Boston

Konikow LF, Bredehoeft JD (1992) Ground-water models cannot be validated. Adv Water Resour 15:75-83

Leibundgut C, Maloszewski P, Kulls C (2009) Tracers in hydrology. Blackwell, Oxford, UK

Leube A, Hirdes W (1986) The Birimian Supergroup of Ghanadepositional environment, structural development and conceptual model of an early Proterozoic suite. Rep. No. 99529, Arch. BGR, Hannover, p 260

Lin J, Snodsmith JB, Zheng C, Wu J (2009) A modeling study of seawater intrusion in Alabama Gulf Coast. USA Environ Geol $57: 119-130$

Lutz A, Thomas JM, Pohll G, McKay WA (2007) Groundwater resource sustainability in the Nabogo Basin of Ghana. J Hydrol 49:61-70

McLaren RG, Forsyth PA, Sudicky EA, VanderKwaak JE, Schwartz FW, Kessler JH (2000) Flow and transport in fractured tuff at Yucca Mountain: numerical experiments on fast preferential flow mechanisms. J Contam Hydrol 43:211-238

Neville CJ, Ibaraki M, Sudicky EA (2000) Solute transport with multiprocess nonequilibrium: a semi-analytical solution approach. J Contam Hydrol 44:141-159

Ophori DU (1999) Constraining permeabilities in a large-scale groundwater system through model calibration. J Hydrol 224:1-20

Park C-H, Aral MM (2004) Multi-objective optimization of pumping rates and well placement in coastal aquifers. J Hydrol 290:80-99

Pelig-Ba KB (2000) Hydrogeochemistry of the Birrimian metasediments and the Voltaian sediments of the northern region of Ghana (PhD Thesis). University of Reading, Reading, UK

Spiteri C, Slomp CP, Regnier P, Meile C, Cappellen PV (2007) Modelling the geochemical fate and transport of wastewaterderived phosphorus in contrasting groundwater systems. J Contam Hydrol 92:87-108

Uddameri V, Kuchanur M (2007) Simulation-optimization approach to assess groundwater availability in Refugio County, TX. Environ Geol 51:921-929

Yidana SM (2011a) Groundwater flow modeling and particle tracking for chemical transport in the southern Voltaian, aquifers, Ghana. J Environ Earth Sci 63(4):709-721. doi:10.1007/s12665-010$0740-\mathrm{y}$

Yidana S (2011) Groundwater Resources Management For Productive Uses: An assessment of the quality and quality control parameters of groundwater resources in the Afram Plains area, Ghana. Lambert Academic Publishing, ISBN 9783843386760, 142

Yidana SM (2013) Stable isotope characteristics of groundwater in the Voltaian Basin: an evaluation of the role of meteoric recharge in the basin. J Hydrogeol Hydrol Eng 2(2):1-10

Yidana SM, Chegbeleh LP (2013) The hydraulic conductivity field and groundwater flow in the unconfined aquifer system of the Keta Strip, Ghana. J Afr Earth Sci 86:45-52

Yidana SM, Koffie E (2014) The groundwater recharge regime of some slightly metamorphosed neoproterozoic sedimentary rocks: an application of natural environmental tracers. Hydrol Process 28:3104-3117

Yidana SM, Ganyaglo S, Banoeng-Yakubo B, Akabzaa T (2011) A conceptual framework of groundwater flow in some crystalline 
rock aquifers in southeastern Ghana. J Afr Earth Sci 59:185-194. doi:10.1007/s12665-010-0740-y

Yidana SM, Alfa B, Banoeng-Yakubo B, Addai MO (2012) Simulation of groundwater flow in a crystalline rock aquifer system in Southern Ghana-an evaluation of the effects of increased groundwater abstraction on the aquifers using a transient groundwater flow model. Hydrol Process. doi:10. 1002/hyp.9644

Zhang Q, Volker RE, Lockington DA (2004) Numerical investigation of seawater intrusion at Gooburrum, Bundaberg, Queensland, Australia. Hydrogeol J 12:674-687 